Original article

\title{
Community participation in the provision of environmental sanitation infrastructure
} in Akure, Nigeria

\author{
Omotayo B. Olugbamila1*, Samson A. Adeyinka ${ }^{1}$, Oluwafemi M. Odunsi², Sanya A. Olowoyo ${ }^{3}$, \\ Oluwadara L. Isola ${ }^{1}$, Tolulope D. Adanlawo ${ }^{1}$ \\ 1 Department of Urban and Regional Planning, Obafemi Awolowo University, Ile-Ife, Nigeria \\ ${ }^{2}$ Department of Urban and Regional Planning, Olabisi Onabanjo University, Ago-Iwoye, Nigeria \\ 3Department of Architectural Technology, Rufus Giwa Polytechnic, Owo, Nigeria \\ E-mail address (*corresponding author): olugbamilao@gmail.com \\ ORCID iD: Omotayo B. Olugbamila: https://orcid.org/0000-0001-5641-9917; Samson A. Adeyinka: https://orcid.org/0000-0001- \\ 8716-6262; Oluwafemi M. Odunsi: http://orcid.org/0000-0002-6127-0835; Sanya A. Olowoyo: https://orcid.org/0000-0002- \\ 3828-1130; Oluwadara L. Isola: https://orcid.org/0000-0003-3162-9904; Tolulope D. Adanlawo: https://orcid.org/0000-0002- \\ $2062-3884$
}

\begin{abstract}
This article assessed community participation in the provision of environmental sanitation infrastructure in Akure, Nigeria. A multi-stage sampling procedure was employed for the study. Four residential zones: the traditional core, the transition zone, the peripheral zone and the public housing district were identified, this was with a view to showcasing the variation in the level of contributions and efforts of different communities based on the delineated areas towards the provision of environmental sanitation infrastructure in the study area. Twenty residential areas were identified across the residential zones of the study area out of which ten areas which represented $50 \%$ of the total areas were selected. Ten percent of the total number of buildings in the selected areas were subsequently sampled, resulting in the selection of 180 residents for questionnaire administration. The data collected were analysed using descriptive statistics with frequency used for univariate analysis and cross tabulation for bivariate and multivariate analysis as well as the use of chi-square for inferential statistics. Findings revealed that community participation did not play a leading role in providing environmental sanitation facilities in Akure, but that the government did. This shows that most of the environmental facilities in the area are provided by the government, thus revealing the overdependence of the residents on the government for the provision of environmental sanitation infrastructure. Further findings revealed that most of the challenges faced in the study area in terms of providing environmental sanitation infrastructure had a significant influence on the provision of these facilities. Thus, the study showed that challenges significantly hindered the provision of environmental sanitation facilities in the area.

KEY WORDS: Sanitation exercise, citizen participation, environmental facilities, environmental amenities, urbanisation, urban planning
\end{abstract}

ARTICLE HISTORY: received 3 March 2020; received in revised form 20 June 2020; accepted 13 August 2020

\section{Introduction}

Cities serve as engines of growth and opportunities in both the developed and developing countries through provision of employment, education and markets for all kinds of products and services (MILLER, 2014; UNECA, 2017; BENNA, 2019). In most developing countries, the opportunities available in cities have led to a high rate of population growth which has outstripped the rate of infrastructure development and service provision (TUROK \& MCGRANAHAN, 2013; DURANTON, 2014; SELOD, 2017). Infrastructure has been described as a necessary ingredient for the effective growth and functioning of towns and cities and for the national promotion of social and physical 
development activities (OLugBamila, 2008). AYODELE (1996) suggested that there are both economic and social dimensions to the term; the social infrastructure sub-sector covers social services such as education, health services, information, town and country planning and social welfare services generally in society. The economic infrastructure sub sector covers the hardcore economic activities, which relate to the provision of energy, power, transportation services, and water and communication services. These are referred to as utilities, thus the term infrastructure covers both social services and utilities. Infrastructure therefore represents a wide range of economic and social amenities which are crucial to create an enabling environment for sustainable urban growth

The increasing explosive demand for infrastructure among residents of an area has paved the way for various providers of infrastructure; ranging from private institutions to community effort as well as the conventional provider which is the government. In most countries, infrastructure delivery is primarily the responsibility of the government. In Nigeria for example, the provision of infrastructure is the responsibility and obligation of the government at three tiers (federal, state and local government authorities) through established public agencies. The Ministry of Works and Transport is responsible for the construction of roads, the State Water Corporations or Boards are responsible for the provision of water supply while the Transmission Company of Nigeria (TCN) manages the electricity (power supply) transmission network in the country. The Local Government Authorities (LGAs) are responsible for the provision of the environmental sanitation infrastructure in their areas although only a few have the resources and skills to address the problem. However, due to rapid urbanisation and insufficient funding, private provision is gradually gaining ground in developing countries because of government failure caused by the increased pace of urbanisation, dwindling resources, under-pricing, low productivity, poor service delivery and lack of transparency (WORLD BANK, 2004).

Although the problem of infrastructure provision is a global phenomenon, it is more prominent and least attended to in developing nations. The problem becomes severe especially in Nigeria where water supply, sewerage, sanitation, drainage, roads, electricity, waste disposal are virtually non-existent. Maintenance of the partially existing ones is negligible (OLUGBAMILA, 2016). All these are being compounded by the twin problems of rapid population growth and urbanization (OLUBA, 2008).

One of the ways of addressing this inadequate, inefficient and lack of maintenance of infrastructure facilities is through environmental sanitation. It involves the act or activity aimed at maintaining or improving the standard of basic environmental conditions affecting human wellbeingby reducing exposure to diseases through providing a hygienic environment to live in as well as measures to break the cycle of diseases (SCHERTENLEIB \& DIONYS, 2002). Environmental sanitation also involves the state of creating a clean and safe water supply, clean and safe ambient air, efficient and safe animal, human, and industrial waste disposal, protection of food from biological and chemical contaminants, and adequate housing in clean and safe surroundings (ACHEAMPONG, 2010). OYANGO \& UWUSE (2017) described it as the state of excreta, vector and pest control as well as the management of solid waste and water waste. Environmental sanitation thus encompasses the management of human behaviour and sanitation facilities which work together in achieving a hygienic environment (WORLD BANK, 2002), all of which have a significant beneficial impact on health, at local, regional and global scales (ACHEAMPONG, 2010).

Despite the significance of environmental sanitation, research (WHO, 2004; MARA ET AL., 2010; DARAMOLA \& OLOWOPOROKU, 2016; FANIRAN \& 0J0, 2019) has shown that urban areas in most developing counties have been experiencing a lack of, or inadequate, environmental infrastructure including water, drainage and solid waste facilities and services, thus resulting in sanitation problems. It has thus been observed that the demands for urban services and sanitation infrastructure have gone beyond the capacity of governments as a result of the explosive population which greatly limits a government's ability to provide the needed services. The failure of government in this regard has created an avenue where all other stakeholders have had a role to play in bringing to the table different resources during the different processes of environmental management, hence the role of the ubiquitous 'community' as the primary stakeholder in the process (UNEP, 2005).

The role of the community in the development process has been interpreted as community participation in the literature (ONIBOKUN \& FANIRAN, 1995; MUSA \& IFATIMEHIN, 2011; ODUNOLA \& ODUNSI, 2017, 2018). Its importance in the success of any project cannot be overemphasized. This has prompted many researchers to look into its importance in different fields and dimensions (GOMEZ \& GRAHAM, 2003; DWIVEDI \& SHARMA, 2007; 
ACHEAMPONG, 2010; DARAMOLA, 2011; OdUnOLA ET AL., 2018). The notion of community participation is based on the assumption that there is "a community" and the elements of this community interact together for the progress of their habitat, in the form called "participation". Community participation therefore according to VAUGHN (1972) cited in ADANLAWO, (2015) is the involvement of people from the earliest stages of the development process, as opposed to simply asking their opinion of project proposals that have already been developed, or for their contribution to the implementation of projects imposed from outside. He further stated that participatory approaches have been widely tested in the fields of water, sanitation and hygiene, and experience has shown that involvement of the community can produce wide-ranging benefits. Community participation calls for people to partake in planning, implementing and managing their local environment. Community participation means a readiness on the part of both local governments and the citizens to accept equal responsibilities and activities in managing their surroundings (UNEP, 2005). MUSA \& IFATIMEHIN (2011) described it as the financial, physical or social involvement of the people in a community in certain projects embarked upon to solve their own problems. Community participation is therefore necessary to ensure that both government and the resident communities grow closer to each other especially in infrastructure provision (NHLAKANIPHO, 2010 cited in FAKERE \& AYOOLA, 2018). With the clamour for community participation in development project delivery, one might think that the investment by households and communities to improve their homes and neighbourhoods significantly exceeds those made by government, although there are no laid down principles or legal provisions in force in regulating the obligation of local communities and individuals in the provision of environmental sanitation infrastructure. In the context of this study, is the need to examine the roles of the community in the provision of environmental sanitation infrastructure in Akure, Ondo State, Nigeria. This is with a view to understanding the investment of communities in environmental sanitation infrastructure in that region as well as providing information that could enhance their service delivery systems.

\section{Materials and methods}

The study was conducted in Akure which is a traditional Nigerian city and like other traditional Yoruba towns in the country; it existed long before the advent of British colonial rule in the country. The city is located in Ondo State in the South Western part of Nigeria. Ondo State is one of the 36 states of Nigeria. Akure lies on latitude $7^{\circ} 15^{\prime}$ north of the equator and longitude $5^{\circ} 15^{\prime}$ east of the Greenwich Meridian. It is about 250 metres above sea level. Akure is a medium-sized urban centre and became the provincial headquarters of Ondo province in 1939. It also became the capital city of Ondo State and Local Government Headquarters in 1976. The main area of focus was Akure South Local Government Area (LGA) which was carved out of Akure LGA on 1st October, 1996 (Fig. 1). It occupies a land area of 2,303 square kilometres. The headquarters of the Local Government Area (LGA) is Akure city which doubles as the capital city of the State. The LGA has four zones which are core, transition, peripheral and public housing areas.

This study was interested in the modality as well as the roles of the community towards environmental sanitation improvement, taking provision of the facilities as a focal point in Akure South Local Government Area. This study assessed the socioeconomic characteristics of respondents, availability and types of sanitary facilities, the providers of the facilities, its quality as well as measures of satisfaction towards the use of the provided facilities. To achieve these, data were sourced from both primary and secondary sources, primary data were sourced through on-the-spot assessment (observation) of the study area and administration of a questionnaire which was administered on the identified residential zones of the study area. A multi-stage sampling procedure was employed for this study. The first stage involved the stratification of the study area into four zones, comprising the traditional core, transition, peripheral and public housing districts as delineated by AKInBAmijo (2004). This helped to showcase the variation in the level of contributions and efforts of different communities based on the delineated area towards environmental sanitation in the area. The second stage involved the selection of areas to be sampled using random sampling through the ballot system. Table 1 shows the identified residential zones in the study area. There were twenty identified areas in the different residential zones of the study area, in each zone, one out of every two areas was selected without replacement which translated to ten areas which represent $50 \%$ of the total areas identified in the four zones of the study area. The third stage involved the use of systematic sampling techniques in selecting buildings and respondents for the purpose of the questionnaire administration. In this stage, a total of 1,803 
residential buildings were first identified in the study area as extracted from Google Earth images (Table 1). Subsequently, ten percent of the total number of buildings in the selected areas was sampled, resulting in selection of 180 residents for questionnaire administration (Table 1).

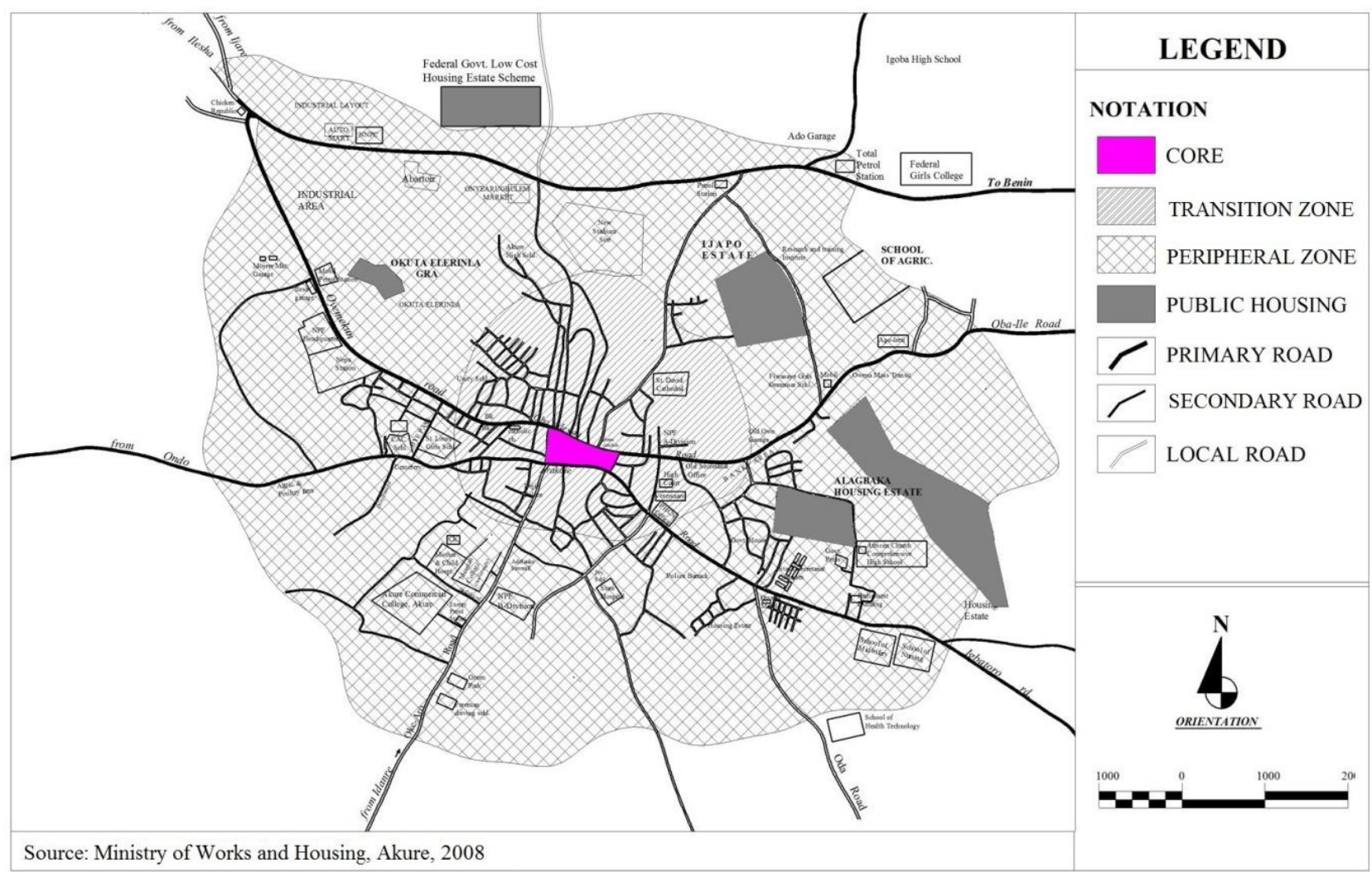

Fig. 1. Map of Akure indicating the zones and major roads (Source: Ministry of Works and Housing, Akure, 2008)

Table 1. Sampled buildings and sample size in selected areas in the identified residential zones (Source: Akinbamijo, 2004; Google Earth Estimates, 2010)

\begin{tabular}{|c|c|c|c|c|c|}
\hline Residential zone & Identified areas & Selected area & $\begin{array}{l}\text { Number of } \\
\text { buildings }\end{array}$ & $\begin{array}{c}\text { Identified } \\
\text { buildings }(10 \%)\end{array}$ & Total \\
\hline \multirow[t]{8}{*}{ Core } & Araromi & \multirow[t]{2}{*}{ Araromi } & \multirow[t]{2}{*}{104} & \multirow[t]{2}{*}{10} & \multirow{8}{*}{81} \\
\hline & Oritagun & & & & \\
\hline & Odo-Ikoyi & \multirow[t]{2}{*}{ Odo-Ikoyi } & \multirow[t]{2}{*}{256} & \multirow[t]{2}{*}{26} & \\
\hline & Igann & & & & \\
\hline & Isolo & \multirow[t]{2}{*}{ Isolo } & \multirow[t]{2}{*}{366} & \multirow[t]{2}{*}{37} & \\
\hline & Erekefa & & & & \\
\hline & Oja Oshodi & \multirow[t]{2}{*}{ Oja Oshodi } & \multirow[t]{2}{*}{84} & \multirow[t]{2}{*}{8} & \\
\hline & Eruoba & & & & \\
\hline \multirow[t]{6}{*}{ Transition } & Oke Aro & \multirow[t]{2}{*}{ Oke Aro } & \multirow[t]{2}{*}{108} & \multirow[t]{2}{*}{11} & \multirow{6}{*}{27} \\
\hline & Oke Padi & & & & \\
\hline & Nepa area & \multirow[t]{2}{*}{ Nepa area } & \multirow[t]{2}{*}{66} & \multirow[t]{2}{*}{7} & \\
\hline & Oke Arata & & & & \\
\hline & Aiyedun & \multirow[t]{2}{*}{ Ayedun } & \multirow[t]{2}{*}{94} & \multirow[t]{2}{*}{9} & \\
\hline & OkeIsinkan & & & & \\
\hline \multirow[t]{4}{*}{ Peripheral } & Aule Road & \multirow[t]{2}{*}{ Aule Road } & \multirow[t]{2}{*}{308} & \multirow[t]{2}{*}{31} & \multirow{4}{*}{46} \\
\hline & Gaga Area & & & & \\
\hline & Ijoka & \multirow[t]{2}{*}{ Ijoka } & \multirow[t]{2}{*}{153} & \multirow[t]{2}{*}{15} & \\
\hline & Jegele & & & & \\
\hline Public housing districts & $\begin{array}{l}\text { Shagari } \\
\text { Ijapo }\end{array}$ & Shagari & 264 & 26 & 26 \\
\hline Total & 20 & 10 & 1,803 & 180 & 180 \\
\hline
\end{tabular}

Source: Authors field survey, 2019 
Secondary data on the population of the study area were obtained from the National Population Commission (NPC). The study population comprised the residents of Akure, with the sampling frame being residents in the delineated zones. Data collected were analysed using both the descriptive and inferential statistics based on the set objectives. Statistical Product and Service Solution Version 20 (SPSS) package (IBM CORP. RELEASED, 2011) was used for the data analysis. Descriptive statistics were frequency for univariate analysis and cross tabulation for bivariate and multivariate analysis and inferential statistics which was chi-square.

\section{Results and discussion}

\subsection{Socio-economic characteristics of respondents}

Relative to this study, the socio economic characteristics explained the residents' pattern of life, perception, and factors that influence the supply of environmental sanitation facilities. Implicit to this is that, this section examines the influence these characteristics have on the way and role the community participates in the provision of environmental facilities. The variables discussed included: gender, age, marital status, educational attainment, occupation, average monthly income, length of stay and household size (Table 2). The gender distribution revealed that most of the respondents were male (63.3\%) while only $36.7 \%$ were female. Out of the 180 respondents, $45 \%$ of them reside in the core out of which $27.2 \%$ were male while $17.8 \%$ were female. In the Transition zone, $15.0 \%$ of the respondents of which $10.6 \%$ were male while $4.4 \%$ were female. The peripheral zone had a $25.6 \%$ response rate out of which $15.6 \%$ were male while the remaining $10.0 \%$ were female. Public housing districts had $14.4 \%$ of the total respondents, of which $10.0 \%$ were male while $4.4 \%$ were female and this is in agreement with the findings of YAU (2011) that gender plays a significant role in participation in environmental sanitation infrastructure provision. This is attributed to the fact that the target respondents were the heads of households, due to cultural belief of the study area that men take the leading role in the society.

This variable of the socio-economic characteristics helps differentiate between the dependent age bracket and the working-class age group as well as showing the population of infants, adolescents, adults and the elderly in order to determine the level of expectation where financial contribution is to be made and where decisions pertaining to participation is to be taken. It symbolically shows whether the respondents are still within the liability age bracket or have attained the responsibility age group. The greater number of the respondents 160 (20-40 and 41-60) representing $88.8 \%$ fell within the working-class group while 20 of the respondents (below 20 and above 60 ) representing $11.2 \%$ were within the dependent age bracket. Thus, much expectation in terms of contribution would be expected as most of the people fell within the working-class age bracket in the study area. The marital status of the respondents also has its role to play in the extent of participation. The marital status presented shows that most of the respondents were married $(61.6 \%)$, while $31.7 \%$ of the respondents were still single with a fractional $6.7 \%$ widowed and no representation for divorced. It implies that responsibility level should be high with a high number of married respondents.

Education is believed to make it easy to govern the people but difficult to rule. Based on this assertion it is believed that where educational background is high, information about environmental sanitation will be high and maintained. Education plays an important role in the enlightenment of people not only on personal hygiene but also on good sanitary practices. Thus, it can be deduced that all the respondents were educated, with tertiary education accounting for more than half of the total respondents $(78.3 \%)$, while the remaining $20 \%$ and $1.7 \%$ were secondary school leavers and primary school leavers respectively. It can also be deduced that environmental education through different media should be very high and embraced with maturity as a result of highlevels of education among the residents of the area, thus influencing their decision positively towards participation in the provision of environmental sanitation facilities in the study area.

Employment status is also a determinant of participation in environmental sanitation infrastructure provision, this is because it is when people are gainfully employed that they can earn an income and it is with a higher income that the people will be able to participate in the provision of these facilities. The majority of the respondents (66.7\%) were traders, $29.4 \%$ most of whom resided in the core residential zone engaged in farming activities, while the remaining 3.9\% were civil servants. This agrees with the findings of PLUMMER (2000) that employment status influences the level of participation. Income of respondents is another important variable in the explanation of the level of participation of an individual as well as the community as a whole in the provision of environmental sanitation infrastructure in the study area. The variable determines where and 
how people live as well as the quality of sanitation facilities in homes. More than half of the total respondents (55.6\%) earned below $\$ 20,000$, while $31.1 \%$ of the respondents earned between $\$ 21,000$ and $\$ 60,000$. The remaining $13.3 \%$ of the population earned above $\$ 60,000$. Conventionally, the low-income earners reside in the core area and some part of the transition zone while the high-income earners reside in the peripheral and public housing districts. However, it was shown that the level of income among the respondents in relation to the various residential zones differs from convention. Although a larger percentage of the respondents earned below $\$ 20,000$, a significant number of respondents earned above $\$ 60,000$ thus showing an average economy in terms of their income.

The years of residing in an area also has an influence on the extent of participation in community-oriented programmes. This can be attributed to the social status of residents in the area which is presumed will have increased over a certain period of time. From the summary of the length of stay of residents, $17.8 \%$ had lived in Akure for more than 20 years, with the highest number of respondents (28.9\%) having lived in the area between 6-10 years. Those that had lived in the area for the first five years accounted for $25.6 \%$, while the remaining $17.2 \%$ and $10.6 \%$ of respondents had lived in the area between 1115 years and between 16-20 years respectively. A reasonable length of stay in an area can trigger a community relationship hence participation with a direct influence on projects such as provision of environmental sanitation facilities. The household size distribution showed that $56.7 \%$ of the total respondents had between 4-6 household sizes, which was the highest among the respondents in the study area followed by a household size of 1-3, which accounted for $22.8 \%$. Others included a household size of 7-9 and above 10 which accounted for $15.0 \%$ and $5.6 \%$ respectively.

Table 2. Socio-economic characteristics of respondents

\begin{tabular}{|c|c|c|c|c|c|c|}
\hline \multirow{2}{*}{\multicolumn{2}{|c|}{$\begin{array}{l}\text { Socio-economic } \\
\text { characteristics }\end{array}$}} & \multicolumn{4}{|c|}{ Residential zones } & \multirow{3}{*}{$\begin{array}{l}\text { Total } \\
114(63.3)\end{array}$} \\
\hline & & \multirow{2}{*}{$\begin{array}{l}\text { Core } \\
49(60.5)\end{array}$} & \multirow{2}{*}{$\begin{array}{c}\text { Transition } \\
19(70.4)\end{array}$} & \multirow{2}{*}{$\begin{array}{c}\text { Peripheral } \\
28(160.9)\end{array}$} & \multirow{2}{*}{$\begin{array}{r}\text { Public housing } \\
18(69.2)\end{array}$} & \\
\hline Gender & Male & & & & & \\
\hline & Female & $32(39.5)$ & $8(38.6)$ & $18(39.1)$ & $8(30.8)$ & $66(36.7)$ \\
\hline & Total & $81(100.0)$ & $27(100.0)$ & $46(100.0)$ & $26(100.0)$ & $180(100.0)$ \\
\hline \multirow[t]{5}{*}{ Age } & $<20$ & $2(2.5)$ & $0(0.0)$ & $3(6.5)$ & $1(3.8)$ & $6(3.4)$ \\
\hline & $20-40$ & $44(54.3)$ & $12(44.4)$ & $21(45.7)$ & $12(46.2)$ & $89(49.4)$ \\
\hline & $41-60$ & $27(33.3)$ & $13(48.2)$ & $19(41.3)$ & $12(46.2)$ & $71(39.4)$ \\
\hline & $>60$ & $8(9.9)$ & $2(7.4)$ & $3(6.5)$ & $1(3.8)$ & $14(7.8)$ \\
\hline & Total & $81(100.0)$ & $27(100.0)$ & $46(100.0)$ & $26(100.0)$ & $180(100.0)$ \\
\hline \multirow[t]{4}{*}{ Marital status } & Single & $26(32.1)$ & $8(29.6)$ & $13(28.3)$ & $10(38.5)$ & $57(31.7)$ \\
\hline & Married & $47(58.0)$ & $18(66.7)$ & $32(69.6)$ & $14(53.8)$ & $111(61.6)$ \\
\hline & Widowed & $8(9.9)$ & $1(3.7)$ & $1(2.1)$ & $2(7.7)$ & $12(6.7)$ \\
\hline & Total & $81(100.0)$ & $27(100.0)$ & $46(100.0)$ & $26(100.0)$ & $180(100.0)$ \\
\hline \multirow[t]{4}{*}{ Education } & Primary & $3(3.7)$ & $0(.0)$ & $0(.0)$ & $0(.0)$ & $3(1.7)$ \\
\hline & Secondary & $18(22.2)$ & $3(11.1)$ & $9(19.6)$ & $6(23.1)$ & $36(20.0)$ \\
\hline & Tertiary & $60(74.1)$ & $24(88.9)$ & $37(80.4)$ & $20(76.9)$ & $141(78.3)$ \\
\hline & Total & $81(100.0)$ & $27(100.0)$ & $46(100.0)$ & $26(100.0)$ & $180(100.0)$ \\
\hline \multirow[t]{4}{*}{ Occupation } & Trading & $52(64.2)$ & $22(81.5)$ & $27(58.7)$ & $18(69.2)$ & $120(66.7)$ \\
\hline & Farming & $24(29.6)$ & $5(18.5)$ & $16(34.8)$ & $8(30.8)$ & $53(29.4)$ \\
\hline & Civil servant & $5(6.2)$ & $0(.0)$ & $3(6.5)$ & $0(.0)$ & $7(3.9)$ \\
\hline & Total & $81(100.0)$ & $27(100.0)$ & $46(100.0)$ & $26(100.0)$ & $180(100.0)$ \\
\hline \multirow[t]{4}{*}{ Income } & $<\# 20,000$ & $52(60.5)$ & $13(48.2)$ & $25(54.3)$ & $10(38.5)$ & $100(55.6)$ \\
\hline & $\$ 20-60,000$ & $26(35.8)$ & $11(40.7)$ & $13(28.3)$ & $6(23.0)$ & $56(31.1)$ \\
\hline & $>=0,000$ & $3(3.7)$ & $3(11.1)$ & $8(17.4)$ & $10(38.5)$ & $24(13.3)$ \\
\hline & Total & $81(100.5)$ & $27(100.0)$ & $46(100.0)$ & $26(100.0)$ & $180(100.0)$ \\
\hline \multirow{6}{*}{$\begin{array}{l}\text { Length of } \\
\text { stay }\end{array}$} & $1-5$ & $26(32.1)$ & $4(14.8)$ & $11(23.9)$ & $5(19.2)$ & $46(25.6)$ \\
\hline & $6-10$ & $20(24.7)$ & $10(37.0)$ & $12(26.1)$ & $10(38.5)$ & $52(28.9)$ \\
\hline & $11-15$ & $14(17.3)$ & $5(18.5)$ & $10(21.7)$ & $2(7.7)$ & $31(17.2)$ \\
\hline & $16-20$ & 11(13.6) & $2(7.4$ & $4(8.7)$ & $2(7.7)$ & 19(10.6) \\
\hline & $>20$ & $10(12.3)$ & $6(22.2)$ & $9(19.6)$ & $7(26.9)$ & $32(17.7)$ \\
\hline & Total & $81(100.0)$ & $27(100.0)$ & $46(100.0)$ & $26(100.0)$ & $180(100.0)$ \\
\hline \multirow{5}{*}{$\begin{array}{l}\text { Household } \\
\text { size }\end{array}$} & $1-3$ & $17(21.0)$ & $6(22.2)$ & $14(30.4)$ & $4(15.4)$ & $41(22.8)$ \\
\hline & $4-6$ & $46(56.8)$ & $14(51.9)$ & $26(56.5)$ & $16(61.6)$ & $102(56.7)$ \\
\hline & $7-9$ & $10(12.3)$ & $6(22.2)$ & $6(13.1)$ & $5(19.2)$ & $27(15.0)$ \\
\hline & $10-15$ & $8(9.9)$ & $1(3.7)$ & $0(.0)$ & $1(3.8)$ & $10(5.5)$ \\
\hline & Total & $81(100.0)$ & $27(100.0)$ & $46(100.0)$ & $26(100.0)$ & $180(100.0)$ \\
\hline
\end{tabular}




\subsection{Providers of environmental sanitation infrastructure}

This section discusses the results of providers of environmental sanitation facilities in the study area. Table 3 shows that the provider of boreholes was mostly the government as witnessed across all the residential zones in the study area, while the community were also involved in the provision although second to government in this capacity.
Household role had no record among the respondents in the provision of boreholes. Therefore, it can be deduced that the government provides more boreholes than the community or any other stakeholders in the study area. The chisquare result (Table 4) showed that there was no significant relationship in the providers of boreholes and the drilling of boreholes across the four delineated residential zones of the study area.

Table 3. Providers of Boreholes across residential zones

\begin{tabular}{|c|c|c|c|c|c|}
\hline \multicolumn{3}{|c|}{ Residential zones } & \multicolumn{2}{|c|}{ Borehole } & \multirow{3}{*}{$\begin{array}{l}\text { Total } \\
26(33.3)\end{array}$} \\
\hline & & & \multirow{2}{*}{$\begin{array}{l}\text { Yes } \\
16(20.5)\end{array}$} & \multirow{2}{*}{$\begin{array}{l}\text { No } \\
10(12.8)\end{array}$} & \\
\hline Core & Providers & Community & & & \\
\hline & & Government & $32(41.0)$ & $20(25.6)$ & $52(66.7)$ \\
\hline & \multicolumn{2}{|l|}{ Total } & $48(61.5)$ & $30(38.5)$ & $78(100.0)$ \\
\hline \multirow[t]{3}{*}{ Transition } & \multirow{2}{*}{ Providers } & Community & $8(29.6)$ & 5918.5) & $13(48.1)$ \\
\hline & & Government & $10(37.0)$ & $4(14.8)$ & $14(51.9)$ \\
\hline & \multicolumn{2}{|l|}{ Total } & $18(66.7)$ & $9(33.3)$ & $27(100.0)$ \\
\hline \multirow[t]{3}{*}{ Peripheral } & \multirow[t]{2}{*}{ Providers } & Community & $6(13.0)$ & $6(13.0)$ & $12(26.1)$ \\
\hline & & Government & $19(41.3)$ & $15(32.6)$ & $34(73.9)$ \\
\hline & \multicolumn{2}{|l|}{ Total } & $25(54.3)$ & $21(45.7)$ & $46(100.0)$ \\
\hline \multirow[t]{3}{*}{ Public housing district } & \multirow[t]{2}{*}{ Providers } & Community & $2(7.7)$ & $3(11.5)$ & $5(19.2)$ \\
\hline & & Government & $9(34.6)$ & $12(46.2)$ & $21(80.8)$ \\
\hline & \multicolumn{2}{|l|}{ Total } & $11(42.3)$ & $15(57.7)$ & $26(100.0)$ \\
\hline
\end{tabular}

Source: Authors field survey, 2019

Table 4. Chi-Square summary for providers of boreholes across residential zones

\begin{tabular}{|c|c|c|c|c|c|c|}
\hline \multicolumn{2}{|c|}{ Residential zones } & Value & Df & $\begin{array}{l}\text { Asymp. Sig. } \\
\text { (2-sided) }\end{array}$ & $\begin{array}{l}\text { Exact Sig. } \\
\text { (2-sided) }\end{array}$ & $\begin{array}{l}\text { Exact Sig. } \\
\text { (1-sided) }\end{array}$ \\
\hline \multirow[t]{5}{*}{ Core } & Pearson Chi-Square & .000 & 1 & 1.000 & & \\
\hline & Likelihood Ratio & .000 & 1 & 1.000 & & \\
\hline & Fisher's Exact Test & & & & 1.000 & .595 \\
\hline & Linear-by-Linear Association & .000 & 1 & 1.000 & & \\
\hline & $\mathrm{N}$ of Valid Cases ${ }^{\mathrm{b}}$ & 78 & & & & \\
\hline \multirow[t]{4}{*}{ Transition } & Pearson Chi-Square & .297 & 1 & .586 & & \\
\hline & Likelihood Ratio & .297 & 1 & .586 & & \\
\hline & Linear-by-Linear Association & .286 & 1 & .593 & & \\
\hline & $\mathrm{N}$ of Valid Cases & 27 & & & & \\
\hline \multirow[t]{4}{*}{ Peripheral } & Pearson Chi-Square & .124 & 1 & .725 & & \\
\hline & Likelihood Ratio & .123 & 1 & .725 & & \\
\hline & Linear-by-Linear Association & .121 & 1 & .728 & & \\
\hline & $\mathrm{N}$ of Valid Cases & 46 & & & & \\
\hline \multirow{4}{*}{$\begin{array}{l}\text { Public housing } \\
\text { district }\end{array}$} & Pearson Chi-Square & .014 & 1 & .907 & & \\
\hline & Likelihood Ratio & .014 & 1 & .907 & & \\
\hline & Linear-by-Linear Association & .013 & 1 & .909 & & \\
\hline & $\mathrm{N}$ of Valid Cases & 26 & & & & \\
\hline
\end{tabular}

Source: Authors field survey, 2019

Table 5 shows that in the core residential area, household members were the major providers of toilets for community use and this accounted for $33.8 \%$ while $12.3 \%$ were provided by the community, the government had no significant recognition in the area of provision of toilets in 
the core. In the transition zone, the roles of household members and community members in the provision of toilets are even with $18.5 \%$ from each. This shows equality in the role household members play and the community play in the provision of this facility. The peripheral zone has more household members provision of toilets $(21.7 \%)$ than the community which is represented by $10.9 \%$. The public housing districts follow a similar suit as the peripheral zone with the household members playing a leading role in the provision of toilets for community use with $38.5 \%$, while the community accounted for $3.8 \%$. Thus, households take more responsibility than the community for providing toilets for the community even more than the government, whose role, or effort, is not visible to the residents based on the responses of residents of Akure. The chi-square test (Table 6) showed no significant relationship between the providers of toilets and the number of toilets constructed across the four residential zones of the study area.

Table 5. Providers of toilet facilities across residential zones

\begin{tabular}{|c|c|c|c|c|c|}
\hline & Residen & & Toilets for cor & use & Total \\
\hline Core & Providers & Household members & $31(39.3)$ & $27(333)$ & $58(71.6)$ \\
\hline & & Community & $10(12.3)$ & $13(16.0)$ & $23(28.4)$ \\
\hline & Total & & $41(50.6)$ & $40(49.4)$ & $81(100.0)$ \\
\hline Transition & Providers & Household members & $5(18.5)$ & $12(44.4)$ & $17(63.0)$ \\
\hline & & Community & $5(18.5)$ & $5(18.5)$ & $10(37.0)$ \\
\hline & Total & & $10(37.0)$ & $17(63.0)$ & $27(100.0)$ \\
\hline Peripheral & Providers & Household members & $10(21.7)$ & $21(45.7)$ & $31(67.4)$ \\
\hline & & Community & $5(10.9))$ & $10(21.7)$ & $15(32.6)$ \\
\hline & Total & & $15(32.6)$ & $31(67.4)$ & $46(100.0)$ \\
\hline Public housing & Providers & Household members & $10(38.5)$ & $14(53.8)$ & $24(92.3)$ \\
\hline & & Community & $1(3.8)$ & $1(3.8)$ & $2(7.7)$ \\
\hline & Total & & $11(42.3)$ & $15(57.7)$ & $26(100.0)$ \\
\hline
\end{tabular}

Source: Authors field survey, 2019

Table 6. Chi-Square summary for providers of toilet facilities across residential zones

\begin{tabular}{|c|c|c|c|c|c|c|}
\hline \multicolumn{2}{|c|}{ Residential zones } & \multirow{2}{*}{$\begin{aligned} \text { Value } \\
.655 \\
\end{aligned}$} & \multirow{2}{*}{$\begin{array}{ll}\text { Df } & \\
1 \\
\end{array}$} & \multirow{2}{*}{$\begin{array}{r}\text { Asymp. Sig. } \\
\text { (2-sided) } \\
.418\end{array}$} & \multirow{2}{*}{$\begin{array}{l}\text { Exact Sig. } \\
\text { (2-sided) }\end{array}$} & \multirow{2}{*}{$\begin{array}{l}\text { Exact Sig } \\
\text { (1-sided) }\end{array}$} \\
\hline Core & Pearson Chi-Square & & & & & \\
\hline & Likelihood Ratio & .656 & 1 & .418 & & \\
\hline & Linear-by-Linear Association & .647 & 1 & .421 & & \\
\hline & $\mathrm{N}$ of Valid Cases & 81 & & & & \\
\hline \multirow[t]{4}{*}{ Transition } & Pearson Chi-Square & 1.144 & 1 & .285 & & \\
\hline & Likelihood Ratio & 1.134 & 1 & .287 & & \\
\hline & Linear-by-Linear Association & 1.102 & 1 & .294 & & \\
\hline & $\mathrm{N}$ of Valid Cases & 27 & & & & \\
\hline \multirow[t]{4}{*}{ Peripheral } & Pearson Chi-Square & .005 & 1 & .942 & & \\
\hline & Likelihood Ratio & .005 & 1 & .942 & & \\
\hline & Linear-by-Linear Association & .005 & 1 & .942 & & \\
\hline & $\mathrm{N}$ of Valid Cases & 46 & & & & \\
\hline \multirow{4}{*}{$\begin{array}{l}\text { Public housing } \\
\text { district }\end{array}$} & Pearson Chi-Square & .053 & 1 & .819 & & \\
\hline & Likelihood Ratio & .052 & 1 & .820 & & \\
\hline & Linear-by-Linear Association & .051 & 1 & .822 & & \\
\hline & $\mathrm{N}$ of Valid Cases & 26 & & & & \\
\hline
\end{tabular}

Source: Authors field survey, 2019 
Table 7 shows a poor response rate as the government is believed to be the major provider in terms of constructing drains for waste water and storm water, with little or insignificant effort of the community at providing this environmental sanitation facility. This is further ascertained by the chi-square test result (Table 8) which showed an insignificant relationship in the providers of drains and the number of drains constructed.

In the provision of waste collection facilities, the household members were the major provider
(39.5\%) of this environmental sanitation facility more than the community $(17.3 \%)$ and the government $(11.1 \%)$ in the core area (Table 9 ). At the transition zone, 33.3\% represented household members that provided waste collection facilities in the zone, while the remaining $22.2 \%$ and $7.4 \%$ of the respondents respectively attested that the community and government provided this environmental sanitation facility.

Table 7. Providers of drains across residential zones

\begin{tabular}{|c|c|c|c|c|c|}
\hline \multirow{2}{*}{\multicolumn{3}{|c|}{ Residential zones }} & \multicolumn{2}{|c|}{ Drains } & \multirow{3}{*}{$\begin{array}{l}\text { Total } \\
11(100.0)\end{array}$} \\
\hline & & & \multirow{2}{*}{\begin{tabular}{l}
\multicolumn{1}{l}{ Yes } \\
$4(36.4)$
\end{tabular}} & \multirow{2}{*}{$\begin{array}{l}\frac{\text { No }}{7(63.6)} \\
7\end{array}$} & \\
\hline Core & Providers & Government & & & \\
\hline & \multicolumn{2}{|l|}{ Total } & $4(36.4)$ & $7(63.6)$ & $11(100.0)$ \\
\hline \multirow[t]{2}{*}{ Transition } & Providers & Government & $1(16.7)$ & $5(83.3)$ & $6(100.0)$ \\
\hline & \multicolumn{2}{|l|}{ Total } & $1(16.7)$ & $5(83.3)$ & $6(100.0)$ \\
\hline \multirow[t]{3}{*}{ Peripheral } & \multirow[t]{2}{*}{ Providers } & Community & $1(9.1)$ & $1(9.1)$ & $2(18.2)$ \\
\hline & & Government & $4(36.4)$ & $5(45.5)$ & $9(81.8)$ \\
\hline & \multicolumn{2}{|l|}{ Total } & $5(45.5)$ & $6(54.5)$ & $11(100.0)$ \\
\hline \multirow[t]{3}{*}{ Public housing district } & \multirow{2}{*}{$\begin{array}{l}\text { Providers of } \\
\text { drains }\end{array}$} & Community & $0(0.0)$ & $1(12.5)$ & $1(12.5)$ \\
\hline & & Government & $1(12.5)$ & $6(75.0)$ & $7(87.5)$ \\
\hline & \multicolumn{2}{|l|}{ Total } & $1(12.5)$ & $7(87.5)$ & $8(100.0)$ \\
\hline
\end{tabular}

Source: Authors field survey, 2019

Table 8. Chi-Square summary for providers of drains across residential zones

\begin{tabular}{|c|c|c|c|c|c|c|}
\hline \multicolumn{2}{|c|}{ Residential zones } & \multirow{2}{*}{$\begin{array}{l}\text { Value } \\
\qquad .^{\mathrm{a}}\end{array}$} & \multirow[t]{2}{*}{ Df } & \multirow{2}{*}{$\begin{array}{l}\text { Asymp. Sig. } \\
\text { (2-sided) }\end{array}$} & \multirow{2}{*}{$\begin{array}{l}\text { Exact Sig. } \\
\text { (2-sided) }\end{array}$} & \multirow{2}{*}{$\begin{array}{l}\text { Exact Sig. } \\
\text { (1-sided) }\end{array}$} \\
\hline Core & Pearson Chi-Square & & & & & \\
\hline & $\mathrm{N}$ of Valid Cases & 11 & & & & \\
\hline \multirow[t]{2}{*}{ Transition } & Pearson Chi-Square &.$^{a}$ & & & & \\
\hline & $\mathrm{N}$ of Valid Cases & 6 & & & & \\
\hline \multirow[t]{6}{*}{ Peripheral } & Pearson Chi-Square & $020^{\mathrm{b}}$ & 1 & .887 & & \\
\hline & Continuity Correctionc & .000 & 1 & 1.000 & & \\
\hline & Likelihood Ratio & .020 & 1 & .887 & & \\
\hline & Fisher's Exact Test & & & & 1.000 & .727 \\
\hline & $\begin{array}{l}\text { Linear-by-Linear } \\
\text { Association }\end{array}$ & .019 & 1 & .892 & & \\
\hline & N of Valid Cases & 11 & & & & \\
\hline \multirow{6}{*}{$\begin{array}{l}\text { Public housing } \\
\text { district }\end{array}$} & Pearson Chi-Square & $.163^{\mathrm{d}}$ & 1 & .686 & & \\
\hline & Continuity Correctionc & .000 & 1 & 1.000 & & \\
\hline & Likelihood Ratio & .287 & 1 & .592 & & \\
\hline & Fisher's Exact Test & & & & 1.000 & .875 \\
\hline & $\begin{array}{l}\text { Linear-by-Linear } \\
\text { Association }\end{array}$ & .143 & 1 & .705 & & \\
\hline & $\mathrm{N}$ of Valid Cases & 8 & & & & \\
\hline \multicolumn{7}{|c|}{ a. No statistics were computed because Providers of drains is a constant. } \\
\hline \multicolumn{7}{|c|}{ b. 4 cells (100.0\%) have an expected count less than 5 . The minimum expected count is 91 . } \\
\hline \multicolumn{7}{|c|}{ c. Computed only for a $2 \times 2$ table } \\
\hline \multicolumn{7}{|c|}{ d. 3 cells $(75.0 \%)$ have an expected count less than 5 . The minimum expected count is .13 . } \\
\hline
\end{tabular}

Source: Authors field survey, 2019 
A similar situation was evident in the peripheral zone with $32.6 \%$ representing the household provision of waste collection facilities, while the community and government had thesame response rate of $19.6 \%$ each as the provider of this facility. The public housing districts were not different from other residential zones, as household provision still played the leading role (42.3\%), the community was next with $19.2 \%$, while the government accounted for $11.5 \%$. The provision of waste collection facilities in the study area showed that household members were the major providers, as evidenced across the residential zones. Therefore, the household played the main role in providing these facilities towards ensuring a good and high level of environmental sanitation in the area. The chi-square test (Table 10) showed that there was no significant relationship between the providers of waste collection facilities and the number of waste collection facilities provided.

Table 9. Providers of waste collection facilities across residential zones

\begin{tabular}{|c|c|c|c|c|c|}
\hline \multicolumn{3}{|c|}{ Residential zones } & \multicolumn{2}{|c|}{ Provision of waste collection facilities } & \multirow{3}{*}{$\begin{array}{l}\text { Total } \\
46(58.6)\end{array}$} \\
\hline & & & \multirow{2}{*}{$\begin{array}{l}\text { Yes } \\
32(39.5)\end{array}$} & \multirow{2}{*}{$\frac{\text { No }}{14(17.3)}$} & \\
\hline Core & Providers & Household & & & \\
\hline & & Community & $14(17.3)$ & $7(8.6)$ & $21(25.9)$ \\
\hline & & Government & $9(11.1)$ & $5(6.2)$ & 14(17.3) \\
\hline & Total & & $55(67.9)$ & $26(32.1)$ & $81(100.0)$ \\
\hline \multirow[t]{4}{*}{ Transition } & \multirow[t]{3}{*}{ Providers } & Household & $9(33.3)$ & $9(33.3)$ & $18(66.7)$ \\
\hline & & Community & $6(22.2)$ & $0(0.0)$ & $6(22.2)$ \\
\hline & & Government & $2(7.4)$ & $1(3.7)$ & $3(11.1)$ \\
\hline & \multicolumn{2}{|l|}{ Total } & $17(63.0)$ & $10(37.0)$ & $27(100.0)$ \\
\hline \multirow[t]{4}{*}{ Peripheral } & \multirow[t]{3}{*}{ Providers } & Household & $15(32.6)$ & $7(15.2)$ & $22(47.8)$ \\
\hline & & Community & $9(19.6)$ & $5(10.9)$ & $14(30.4)$ \\
\hline & & Government & $9(19.6)$ & $1(2.2)$ & $10(21.7)$ \\
\hline & \multicolumn{2}{|l|}{ Total } & $33((71.7)$ & $13(28.3)$ & $46(100.0)$ \\
\hline \multirow{4}{*}{$\begin{array}{l}\text { Public } \\
\text { housing } \\
\text { district }\end{array}$} & \multirow[t]{3}{*}{ Providers } & Household & $11(42.3)$ & $5(19.2)$ & $16(61.5)$ \\
\hline & & Community & $5(19.2)$ & $1(3.8)$ & $6(23.1)$ \\
\hline & & Government & $3(11.5)$ & $1(3.8)$ & $4(15.4)$ \\
\hline & \multicolumn{2}{|l|}{ Total } & $19(73.1)$ & $7(26.9)$ & $26(100.0)$ \\
\hline
\end{tabular}

Source: Authors field survey, 2019

Table 10. Chi-Square summary for providers of waste collection facilities across residential zones

\begin{tabular}{|c|c|c|c|c|}
\hline \multicolumn{2}{|c|}{ Residential zones } & \multirow{2}{*}{$\begin{aligned} \text { Value } \\
.157^{a}\end{aligned}$} & \multirow{2}{*}{$\begin{array}{l}\text { Df } \\
2\end{array}$} & \multirow{2}{*}{$\begin{array}{l}\begin{array}{l}\text { Asymp. Sig. } \\
\text { (2-sided) }\end{array} \\
.924\end{array}$} \\
\hline Core & Pearson Chi-Square & & & \\
\hline & Likelihood Ratio & .156 & 2 & .925 \\
\hline & Linear-by-Linear Association & .155 & 1 & .694 \\
\hline & $\mathrm{N}$ of Valid Cases & 81 & & \\
\hline \multirow[t]{4}{*}{ Transition } & Pearson Chi-Square & $4.844^{\mathrm{b}}$ & 2 & .089 \\
\hline & Likelihood Ratio & 6.822 & 2 & .033 \\
\hline & Linear-by-Linear Association & 1.948 & 1 & .163 \\
\hline & $\mathrm{N}$ of Valid Cases & 27 & & \\
\hline \multirow[t]{4}{*}{ Peripheral } & Pearson Chi-Square & $2.166^{c}$ & 2 & .339 \\
\hline & Likelihood Ratio & 2.504 & 2 & .286 \\
\hline & Linear-by-Linear Association & 1.137 & 1 & .286 \\
\hline & $\mathrm{N}$ of Valid Cases & 46 & & \\
\hline \multirow[t]{4}{*}{ Public Housing District } & Pearson Chi-Square & $.481^{\mathrm{d}}$ & 2 & .786 \\
\hline & Likelihood Ratio & .509 & 2 & .775 \\
\hline & Linear-by-Linear Association & .200 & 1 & .655 \\
\hline & $\mathrm{N}$ of Valid Cases & 26 & & \\
\hline
\end{tabular}

Source: Authors field survey, 2019 
3.3. Challenges to community participation in environmental sanitation infrastructure

Analysis of the challenges faced in the provision of environmental sanitation infrastructure in Table 11 showed that $34.4 \%$ of the residents across the different residential zones of the study area faced the problem of inadequate funding for the provision of basic environmental sanitation infrastructure, this may be attributed to the fact that the majority of the residents of the study area were low income earners. Those that claimed that a poor education and communication hindered their participation accounted for $24.4 \%$, while $20.6 \%$ represented those that were of the opinion that the uncooperative attitude of the residents of the study area hindered their participation in the provision of these facilities. The remaining 13.9\% and $6.7 \%$ of the population were of the opinion that inadequate manpower and lack of time and busy work schedule respectively were the challenges they faced in their participation in the provision of environmental sanitation infrastructure in the study area. It is evident from the above that the major challenges faced by the residents included a lack of funds and poor education and communication and that this had greatly hindered their participation in the provision of environmental sanitation infrastructure.

Table 11. Challenges to community participation in environmental sanitation infrastructure

\begin{tabular}{|l|r|r|r|r|r|}
\hline \multirow{2}{*}{ Challenges } & \multicolumn{4}{c|}{ Residential zones } & \multirow{2}{*}{ Total } \\
\cline { 2 - 6 } & \multicolumn{1}{|c|}{ Core } & Transition & Peripheral & $\begin{array}{c}\text { Public housing } \\
\text { district }\end{array}$ & \\
\hline Uncooperative attitude of the residents & $12(14.8)$ & $7(25.9)$ & $10(21.7)$ & $8(30.8)$ & $37(20.6)$ \\
\hline Inadequate funding & $32(39.5)$ & $9(33.3)$ & $13(28.3)$ & $8(30.8)$ & $62(34.4)$ \\
\hline Poor education and communication & $20(24.6)$ & $6(22.2)$ & $13(28.3)$ & $5(19.2)$ & $44(24.4)$ \\
\hline Inadequate support from government & $10(12.3)$ & $4(14.8)$ & $7(15.2)$ & $4(15.4)$ & $25(13.9)$ \\
\hline Lack of time and a busy work schedule & $7(8.6)$ & $1(3.7)$ & $3(765)$ & $1(3.8)$ & $12(6.7)$ \\
\hline Total & $81(45.0)$ & $27(15.0)$ & $46(25.6)$ & $26(14.4)$ & $180(100.0)$ \\
\hline
\end{tabular}

Source: Authors field survey, 2019

\section{Conclusion and recommendation}

The study examined community participation in the provision of environmental sanitation infrastructure in Akure, Nigeria. It established among other things that there were significant differences in socio-economic characteristics of the residents across the different residential zones of Akure. The study discovered and concluded that community participation did not play the leading role in providing environmental sanitation facilities in Akure, rather the government provides most of the available environmental sanitation infrastructure, thus revealing the overdependence of the residents on the government for the provision of most of these facilities. It also revealed that most of the challenges faced in the study area in terms of providing environmental sanitation infrastructure had a significant influence on the provision of these facilities. Thus, the study showed that challenges significantly hindered the provision of environmental sanitation facilities in the area.

There is a need therefore for communities to participate in the planning, provision and maintenance of environmental sanitation infrastructure. Also the need for public enlightenment and education programmes through the media, provision of bill boards and posters as well as the organisation of seminars and workshops on the importance of community participation in the provision of these facilities is inevitable. There is a need for the community to see to the maintenance of the available environmental sanitation infrastructure in their domain so as to ensure their sustainability. The community should also devise means or strategies towards ensuring that household members are incorporated into their programs and are motivated to contribute their quota towards provision and delivery of environmental sanitation infrastructure.

\section{References}

Acheampong P.T. 2010. Environmental sanitation in the Kumasi Metropolitan Area (Masters Thesis). Department of Planning, Kwame Nkrumah University of Science and Technology, Kumasi.

Adanlawo T.D. 2015. Community Participation and Environmental Sanitation in Akure, Ondo State (A B.Sc. Dissertation). Department of Urban and Regional Planning, Obafemi Awolowo University, Ile-Ife, Nigeria.

Akinbamijo A.O. 2004. Environmental health and intra urban disparities - a focus on Akure (Doctoral Thesis). Department of Urban and Regional Planning, Federal University of Technology, Akure. 
Ayodele S. 1996. Development and Management of Utilities in Nigeria. Casa Monograph No 9, Malthouse Press Limited, Lagos, Nigeria.

Benna U.G. (Ed.) 2019. Industrial and urban growth policies at the sub-national, national, and global levels. IGI Global.

Daramola O.P. 2011. Community participation and sustainable urban environmental management in Nigeria: a review. [in:] A.T. Salami, 0.0. Orimoogunje (Eds). Environmental research and challenges of sustainable development in Nigeria. Obafemi Awolowo University Press, Ile-Ife: 596-610.

Daramola O.P., Olowoporoku O.A. 2016. Environmental sanitation practices in Osogbo, Nigeria: An assessment of residents' sprucing-up of their living environment. Economic and Environmental Studies, 16, 4: 699-716.

Duranton G. 2014. Growing through cities in developing countries. World Bank, Geneva.

Dwivedi P., Sharma A.N. 2007. Study on environmental sanitation, sanitary habits and personal hygiene among the Baigas of Samnapur Block of Dindori District, Madhya Pradesh. Journal of Human Ecology, 22, 1: 7-10.

Fakere A.A. Ayoola H.A. 2018. Socioeconomic Characteristics and Community Participation in Infrastructure. Provision in Akure, Nigeria, Cogent Social Sciences, 4, 1: 1437013.

Faniran G., Ojo D. 2019. Inequalities in households' environmental sanitation practices in developing nation's city: The example of Ile-Ife, Nigeria. Intech Open.

Gomez J.D., Graham J.P. 2003. Community participation in dry sanitation projects. Water Policy, 6, 2: 249-262.

IBM Corp. Released. 2011. IBM SPSS Statistics for Windows, Version 20.0. IBM Corp., Armonk, NY.

Mara D., Lane J., Scott B., Trouba D. 2010. Sanitation and health. PLOS Medicine, 7, 11: e1000363.

Miller H. 2014. What are the features of urbanisation and cities that promote productivity, employment and salaries. Helpdesk Request. EPS-PEAKS, London.

Musa S.D., Ifatimehin O. O. 2011. Community Participation Course Guide. A Course Guide on ESM 206 at National Open University of Nigeria. Accessed June 2019 at www.nou.edu.ng/noun/NOUN_OCL/pdf/pdf2/ESM\%20 206.pdf

Odunola O., Odunsi 0. 2018. Community based organisations as agents of change in poverty alleviation: measuring households' satisfaction. A compendium on poverty alleviation and deprivation: A Festschrift in honour of Professor David o. Olanrewaju, Federal University of Technology Akure, Nigeria.

Odunola O., Odunsi O. 2017. Contributions of community based organisations to poverty alleviation in Oyo State, Nigeria. Economic and Environmental Studies. Faculty of Economics, University of Opole, Opole, Poland, 17, 2: 185-203.

Odunola O., Odunsi O., Daramola O. 2018. Community-based organizations' development-oriented activities: Assessing participatory bottlenecks and measuring households' willingness using Arnstein's ladder of citizen participation. Economic and Environmental Studies, 18, 4: 1309-1333.

Oluba M. 2008. Who Should Provide Public Infrastructure in Nigeria? Assessed on August 18th, 2020 at https://www. proshareng.com/articles/The-Economy/Who-ShouldProvide- Public-Infrastructure-in-Nigeria/1512.

Olugbamila O.B. 2008. Assessing the Millennium Development Goals for Adequate Water Supply in Owo, Ondo State. [in:] Akinnowo E.0 et al. (ed) Socio-Economic Policies and Millennium Development Goals (MDGs) in Africa Faculty of Social and Management Sciences. Adekunle Ajasin University, Akungba Akoko: 329-335.

Olugbamila O.B. 2016. A study of the Distribution and Patronage Patterns of Healthcare Facilities in Ondo State, Nigeria (Ph.D thesis). Department of Urban and Regional Planning, Obafemi Awolowo University, Ile-Ife, Nigeria.

Onibokun A.G., Faniran A. 1995. Community based organisations in Nigerian urban centers: a critical evaluation of their achievements and potentials as agents of development. (CASSAD) Monograph Series 7. Odua Printing Company Limited.

Oyango M.A., Uwuse M. 2017. Humanitarian response to complex emergencies and natural disasters. [in:] S.R. Quah (Ed.) International Encyclopaedia of Public Health (2nd Edition). Elsevier Academic Press.

Plummer J. 2000. Municipalities and community participation: A sourcebook for capacity building research for department for international development. EarthScan, London.

Schertenleib R., Dionys F. 2002. An Integrated Approach to Environmental Sanitation and Urban Agriculture. Deubendorf, Switzerland.

Selod H. 2017. Opportunities and challenges of urbanisation: Planning for an unprecedented future. Development Research, DEC Policy Research Talk, September 25.

Turok I., McGranahan G. 2013. Urbanization and economic growth: the arguments and evidence for Africa and Asia. Environment and Urbanization, 25, 2: 465-482.

UNECA 2017. Cities are the engine of development, youths their mechanics-Senegal. United Nations Economic Commission for Africa [UNECA], Dakah. Assessed on August 18th, 2020 at http://www.uneca.org/ stories/\%E2\%80\%9Ccities-are-engines-developmentyouths-their-mechanics\%E2\%80\%9D-senegal

UNEP 2005. Environmental Management and Community Participation: Enhancing Local Programmes. United Nations Environment Programme, United Nations Environment Programme, Nairobi.

WHO 2004. The sanitation challenge: turning commitment into reality. World Health Organization (WHO), Switzerland.

Yau Y. 2011. Collectivism and activism in housing management in Hong Kong. Habitat International, 35: 327-334. 